J. MED MICROBIOL --VOL 18 (1984), 277-284

(C) 1984 The Pathological Society of Great Britain and Ireland

\title{
CRYPTIC PLASMIDS IN HOSPITAL ISOLATES OF PROVIDENCIA STUARTI
}

\author{
P. M. Hawkey, P. M. Bennett and Carol A. Hawkey \\ Department of Microbiology, University of Bristol University Walk, Bristol, BS8 ITD
}

\begin{abstract}
SUMmaRY. The distribution of cryptic plasmids among 123 isolates of Providencia stuarti from a hospital ward during a prospective epidemiological study is reported. Two closely related stable plasmids $(34 \mathrm{~Kb}$ and $36 \mathrm{~Kb}$ ) were identified by restriction endonuclease digest analysis of plasmid DNA. One or other of these cryptic plasmids was carried by 40 isolates, the remainder were plasmid-free. A higher proportion of one cryptic plasmid (CPT-A) was found in environmental isolates than in isolates from patients. The serotype of all isolates of P. stuarti was $\mathrm{O} 63$ and they were epidemiologically related. Two of the eight patients colonised by $P$. stuarti carried all three possible variants: plasmid-free (PFI) strains or strains containing cryptic plasmid A (CPT-A) or cryptic plasmid B (CPT-B). The epidemiological significance of these results is discussed.
\end{abstract}

\section{INTRODUCTION}

Detailed studies of the epidemiology of $\mathrm{R}$ factors in various nosocomial gram-negative bacteria have been reported (O'Brien et al., 1980; Tompkins, Plorde and Falkow, 1980; Hughes, Henderson and Datta, 1981; Rubens et al., 1981; Shlaes and Currie, 1983). In these studies, antibiotic resistance markers were used initially to identify the strains of interest. However, a number of naturally-occurring strains of such bacteria contain extrachromosomal replicons that lack identifiable phenotypic characters, such as antibiotic resistance, colicin immunity or conjugal fertility. Plasmids that lack these markers are called cryptic plasmids. Although cryptic plasmids lack a readily identifiable marker, it is reasonable to assume that they confer some desirable property on the bacteria in which they are maintained. In natural environments, bacteria evolve to exploit their habitat to the full. Given that plasmids are a major source of bacterial variation, it must be assumed that the plasmid content of a bacterial population is largely influenced by ecological factors (Tietze and Tschäpe, 1983). There have been few studies of the epidemiological relationships of such cryptic plasmid-containing strains, mainly because of the difficulty in identifying isolates containing cryptic plasmids which, by definition, lack phenotypic markers. The recent introduction of rapid, microscale methods for the isolation of plasmid DNA from crude lysates has facilitated the screening of large numbers of bacterial isolates for plasmid carriage. Digestion of plasmid DNA with restriction endonuc- 
leases provides a very sensitive method with which to identify closely related plasmids. This is particularly important because plasmids of identical, or similar mol. wt may not be identical (Farrar, 1983). Nonetheless, it has been shown that the plasmid profile of an isolate can be used as an epidemiological marker (McGowan et al., 1979).

Studies of the plasmids of Providencia stuarti strains from a known epidemiological background are few and have not included extensive restriction endonuclease analysis of plasmids (McHale, Keane and Dougan, 1981; Tietze and Tschäpe, 1983). We have recently studied the epidemiology of $P$. stuart $i$ in a hospital ward in which colonisation was endemic (Hawkey et al., 1982). The isolates from that study provided an epidemiologically defined collection of strains in which to study the identity and distribution of plasmids by restriction endonuclease digestion.

\section{MATERIALS AND METHODS}

Bacterial strains. Strains of $P$. stuarti were isolated during a colonisation survey in a male geriatric ward; full details of the sources and isolation methods have been reported elsewhere (Hawkey et al., 1982). All isolates in that study were O-serotyped by an established method (Penner et al., 1976).

Storage of bacterial strains. After primary isolation, strains were preserved frozen in a cryoprotective medium at $-70^{\circ} \mathrm{C}$. Overnight cultures of the strains on nutrient agar (Oxoid) were harvested with a bacteriological loop and the growth was suspended in $1 \mathrm{ml}$ of glycerol-citrate medium. This suspension was applied to sterile paper strips $(3 \mathrm{~cm} \times 1 \mathrm{~cm}$; Whatman's No. 1 filter paper) with a disposable glass Pasteur pipette and the strips were heat-sealed in sterile polythene bags $(6 \mathrm{~cm} \times 6 \mathrm{~cm})$; each isolate was stored in triplicate. Glycerol-citrate medium was prepared by mixing $60 \mathrm{ml}$ of a $5 \% \mathrm{w} / \mathrm{v}$ solution of trisodium citrate with $40 \mathrm{ml}$ of glycerol. The medium was dispensed in 1-ml portions in screw-capped bijou bottles and sterilized by autoclaving at $121^{\circ} \mathrm{C}$ for $15 \mathrm{~min}$. Bacteria were recovered by opening the sealed bag with sterile scissors and dropping the filter paper into $10 \mathrm{ml}$ of nutrient broth. This method of bacterial preservation was originally developed by Dr P. C. Fleming, Hospital for Sick Children, Toronto, Canada.

Antibiotic and metal ion susceptibility testing. The minimum inhibitory concentrations (MICs) of antibiotics were determined by the agar dilution method on Diagnostic Sensitivity Test (DST) Agar (Oxoid). Approximately $10^{4} \mathrm{cfu}$ of each isolate were inoculated on to DST agar by a multiple inocula-replicating method (Steers, Foltz and Graves, 1959). Relative susceptibility to metal ions was determined by a qualitative gradient method (Szybalski and Bryson, 1952). Three strains of $P$. stuarti, one plasmid-free (PFI), one with cryptic plasmid A (CPT-A) and one with cryptic plasmid B (CPT-B), were tested for susceptibility to metal ions. Gradient plates were prepared with 1 and $10 \mathrm{~mm}$ solutions of metal salts in $10 \mathrm{ml}$ of Brain Heart Infusion agar (BBL) as the lower sloped layer of agar. This was overlaid with $10 \mathrm{ml}$ of Brain Heart Infusion agar. Plates were left for $18 \mathrm{~h}$ to equilibrate and were inoculated by spotting $10^{4}$ cfu at 10 points across the gradient with an automated multipoint inoculator (Model A400, Denley Instruments, Billingshurst, England). After incubation at $37^{\circ} \mathrm{C}$ for $20 \mathrm{~h}$, the resistance of plasmid-containing and plasmid-free strains was determined by comparison of growth end points. The following metal compounds, in order of increasing atomic numbers, were tested: $\mathrm{KBrO}_{3}, \mathrm{MgCl}_{2}, \mathrm{~K}_{2} \mathrm{Cr}_{2} \mathrm{O}_{7}, \mathrm{MnCl}_{2}, \mathrm{FeSO}_{4}, \mathrm{CoCl}_{2}, \mathrm{NiSO}_{4}, \mathrm{CuSO}_{4}, \mathrm{SnCl}_{2}, \mathrm{~K}_{2} \mathrm{TeO}_{3}, \mathrm{NaIO}_{4}, \mathrm{HgCl}_{2}$, $\mathrm{Pb}\left(\mathrm{C}_{2} \mathrm{H}_{3} \mathrm{O}_{2}\right)_{2}$ (water of hydration has been omitted). To avoid precipitation caused by added sodium chloride, resistance to silver nitrate was tested in Cysteine Lactose Electrolyte-Deficient agar (Oxoid).

Rapid plasmid isolation. A modification of the method attributed to Machida was used (McCormick et al., 1981). A 750- $\mu$ l volume of an 18-h culture in Brain Heart Infusion Broth (BBL) was mixed with an equal volume of the following solution: ethanol $75 \% \mathrm{w} / \mathrm{v}$, crystalline phenol $2 \% \mathrm{w} / \mathrm{v}, 10 \mathrm{~mm}$ EDTA, $20 \mathrm{~mm}$ Tris hydroxymethyl aminomethane hydrochloride (Tris. $\mathrm{HCl}$ ), $p \mathrm{H} 8 \cdot 0$. The cells were pelleted by centrifugation at $12800 \mathrm{~g}$ for $5 \mathrm{~min}$ (Eppendorf microcentrifuge, Model 5414). All the supernate was removed and the tube was inverted for $3 \mathrm{~min}$ over an absorbent surface. The pellet was then resuspended in $200 \mu \mathrm{l}$ of $20 \mathrm{~mm}$ Tris. $\mathrm{HCl}$ 
( $p \mathrm{H} \mathrm{8.0)}$ ), $1 \mathrm{~mm}$ EDTA. Cells were lysed by adding $10 \mu \mathrm{l}$ of $25 \%$ sodium dodecyl sulphate (SDS) and incubating at $37^{\circ} \mathrm{C}$ for $10 \mathrm{~min}$. Cell debris was pelleted by centrifugation at $12800 \mathrm{~g}$ for $15 \mathrm{~min}$ and $60 \mu \mathrm{l}$ of supernate was removed and mixed with $30 \mu \mathrm{l}$ of stop mix reagent (bromphenol blue $0.015 \mathrm{w} / \mathrm{v}$, sucrose $40 \% \mathrm{w} / \mathrm{v}, 0 \cdot 1 \mathrm{M}$ EDTA). Plasmid DNA was separated by vertical agarose slab gel electrophoresis of the $90 \mu \mathrm{l}$ of stop mix plus supernate mixture and was visualised by ethidium bromide staining of the gel and examination over ultra violet light. In another study the method was shown to be capable of detecting plasmids up to at least $65 \mathrm{~Kb}$ in size in strains of $P$. stuarti (unpublished findings).

Isolation of purified plasmid DNA. Purified plasmid DNA was prepared from cells grown overnight in nutrient broth $(250 \mathrm{ml})$ by a modification of a caesium chloride density centrifugation method (Hansen and Olsen, 1978). Plasmid molecular weights were determined by electrophoresis of purified plasmid DNA in an agarose gel with plasmids of known size (pUB $307,54.0 \mathrm{~Kb}$; R388, 34.7 Kb; R1, $101.7 \mathrm{~Kb}$; pUB 918, 76.5 Kb; pACYC 184, 3.9 Kb). Plasmid size was also determined by measuring the contour length of plasmid DNA as previously described (Robinson, Bennett and Richmond, 1977).

Restriction endonuclease digestion. Digests of purified plasmid DNA from all plasmid-positive strains were prepared by the method of Thompson, Hughes and Broda, (1974) with the restriction endonucleases $E c o \mathrm{R} 1$ and $\mathrm{HinCII}$ (Bethesda Research Laboratories, Bethesda, MD, USA). The resulting fragments were separated by electrophoresis in $1 \%$ agarose gels. Fragments of phage lambda DNA generated with $B g I$ were included in each gel as molecular-weight standards.

\section{RESULTS}

The colonisation by $P$. stuarti, serotyping data and epidemiological findings from the geriatric ward that we studied have been reported previously (Hawkey et al., 1982). In the present study only isolates from Ward 2 were examined for plasmid carriage. In summary, all isolates were of serotype 063 , which suggests extensive cross-colonisation; there were no cases of urinary tract infection or bacteraemia. Two of the eight patients were found to be colonised at the beginning of the study; four patients were not colonised on admission but subsequently became colonised. A further two patients admitted during the study period were found to be colonised on first screening, which suggests previous colonisation or acquisition before the weekly screening. Two patterns of colonisation were seen: urinary colonisation alone, and both faecal and urinary colonisation. Faecal carriage of $P$. stuarti was a previously undescribed reservoir for cross-infection. Screening for skin carriage in patients in whom the urine

TABLE

Concentrations of antibiotics inhibiting 50\% (MIC50) and 90\% (MIC90) of 129 isolates of P. stuarti

\begin{tabular}{l|rrc}
\hline & $\begin{array}{l}\text { MIC50 } \\
\text { Antimicrobial agent }\end{array}$ & $\begin{array}{l}\text { MIC90 } \\
(\mathrm{mg} / \mathrm{L})\end{array}$ & $\begin{array}{c}\text { Range of MIC } \\
(\mathrm{mg} / \mathrm{L})\end{array}$ \\
\hline Cephaloridine & $>128$ & $>128$ & $>128$ \\
Ampicillin & 64 & 128 & $32-128$ \\
Carbenicillin & 1 & 2 & $0 \cdot 5-4$ \\
Sulphamethoxazole & $>256$ & $>256$ & $>256$ \\
Trimethoprim & 1 & 2 & $0 \cdot 5-4$ \\
Chloramphenicol & 16 & 16 & $8-16$ \\
Tetracycline & 16 & 32 & $8-32$ \\
Gentamicin & 64 & 64 & $32-128$ \\
Kanamycin & 8 & 16 & $4-16$ \\
Streptomycin & $>256$ & $>256$ & $>256$ \\
& & &
\end{tabular}




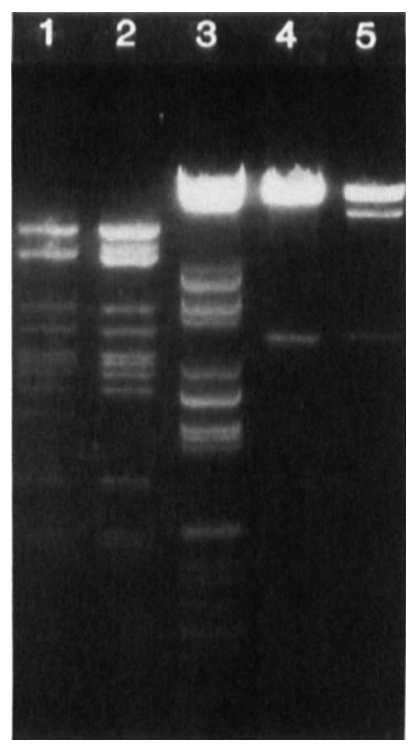

FIG. 1.-Agarose gel electrophoresis of restriction endonuclease-digested fragments of density gradient-purified DNA. DNA in tracks 1 and 2 was digested with HinCII, in tracks 4 and 5 with EcoR 1 . Iracks 1 and 5 contain CPT-B, and tracks 2 and 4 CPT-A. Track 3 contains phage lambda DNA digested with $B g I$ as a mol. wt marker; sizes of fragments (in $\mathrm{Kb}$ ): $10 \cdot 0,8 \cdot 4,3 \cdot 4,2 \cdot 9,2 \cdot 5,2 \cdot 3,2 \cdot 2,1 \cdot 6,1 \cdot 4,1 \cdot 29,1 \cdot 24$, $1 \cdot 12,0 \cdot 82,0 \cdot 80,0 \cdot 69,0 \cdot 63$.

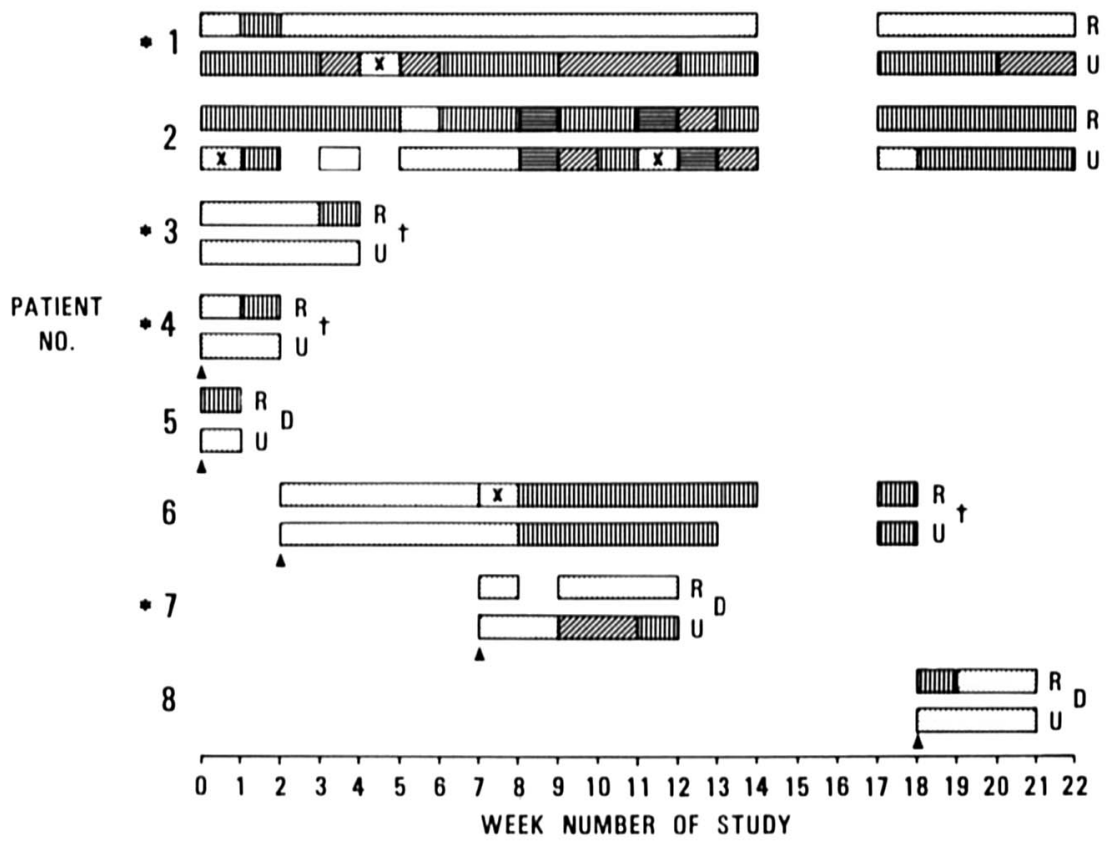

FiG. 2.-Plasmid content and identity based on restriction endonuclease-digest patterns of isolates of $P$. stuart $i$ from patients. $=P$. stuart $i$ not isolated from specimen; $\square=P F I$ strain of $P$. stuart $i$ isolated; $\boldsymbol{D}=\boldsymbol{P}$. stuarti with CPT-A present; $\boldsymbol{\square}=\boldsymbol{P}$. stuarti with CPT-B present; $\boldsymbol{\otimes}=\boldsymbol{P}$. stuarti isolate not examined for plasmid content; $\Delta=$ point of admission to ward; $\mathrm{D}=$ discharged; $\dagger=$ death of patient; * = urinary catheter in situ; $\mathrm{U}=$ urinary colonisation; $\mathrm{R}=$ rectal colonisation. 


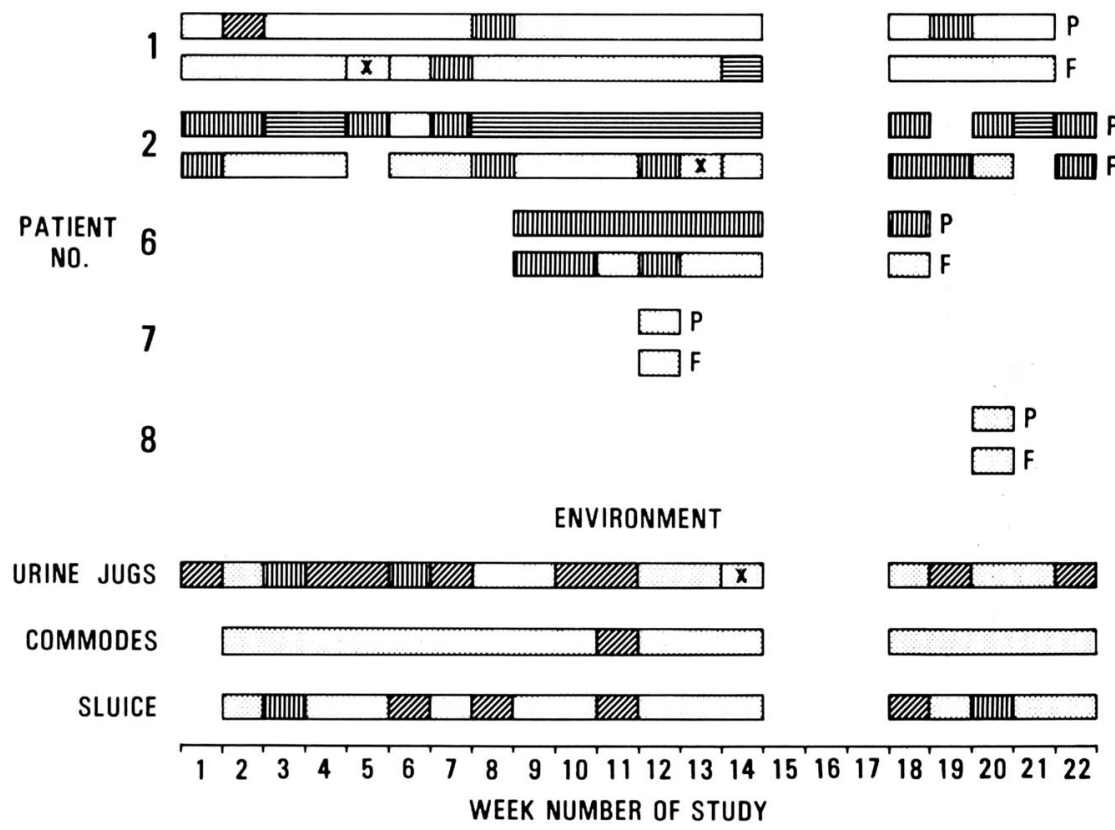

FIG. 3.-Plasmid content and identity based on restriction endonuclease-digest patterns of isolates of $P$. stuarti from patients and from the ward environment. 圈=P. stuart $i$ not isolated from specimen; III = PFI isolate of $P$. stuart $i$ isolated; $=P$. stuarti with CPT-A present; $=P$. stuart $i$ with CPT-B present; $\boldsymbol{\nabla}=\boldsymbol{P}$. stuarti isolate not examined for plasmid content; $\mathrm{P}=\boldsymbol{P}$. stuarti isolated from perineum or buttocks; $\mathrm{F}=P$. stuarti isolated from fingers.

or faeces was colonised with $P$. stuarti was carried out by taking swabs from the perineal and buttock areas and fingers. In addition, a small number of environmental isolates were found, mainly from equipment that may have been contaminated with urine. A total of 130 isolates were obtained of which 123 have been examined for plasmid content.

The results of antimicrobial susceptibility tests are shown in the table. All isolates had similar sensitivity patterns to all antimicrobials and heavy metal ions tested; no difference in sensitivity between plasmid-containing and plasmid-free isolates were observed.

A total of 123 isolates of $P$. stuarti from the patients in Ward 2 and the environment were examined for plasmid carriage by the rapid screening method. Forty of these isolates carried a single plasmid; the remainder were plasmid-free. The size of these plasmids determined by agarose gel electrophoresis was $36 \mathrm{~Kb}$. However, when plasmid DNA was digested with the restriction endonucleases EcoR 1 and $H$ inCII, two fragment patterns were observed; although these were obviously related, clear differences could be seen in the patterns that were generated (fig. 1). Only two plasmid-DNA fragment patterns were seen among the 40 plasmids. These were arbitrarily designated type A and type B. Although no size difference was observed on agarose gel electrophoresis, contour length studies showed plasmids of type A and type $\mathrm{B}$ to be $36 \mathrm{~Kb}$ and $34 \mathrm{~Kb}$ respectively. Because no phenotype could be attributed to the plasmids they are described as cryptic in this paper. The distribution of the two cryptic plasmid types and plasmid-free isolates (PFI) is shown in figs 2 and 3. 
Plasmid-DNA analysis was performed on 16 isolates on at least two occasions, at the start of the study and after storage on Dorset's egg slopes at room temperature for up to 8 months, by restriction endonuclease analysis of $\mathrm{CsCl}$-purified DNA. On no occasion did a plasmid-containing isolate either lose its plasmid or change from carrying CPT-A to CPT-B, which indicates that carriage of these plasmids is very stable.

\section{DisCUSSION}

This investigation has elucidated the distribution of two closely related forms of cryptic plasmid in clinical isolates of $P$. stuarti in a hospital ward environment and in patients. The study illustrates the importance of the use of restriction endonuclease digest data to identify accurately plasmids from epidemiologically-related bacterial isolates, because differences in mol. wt were not detected on electrophoresis gels of intact plasmid DNA. From data presented in figs 2 and 3 it can be seen that $25(63 \%)$ of the 40 plasmid-containing strains carried cryptic plasmid type A (CPT-A) and 15 $(37 \%)$ carried type B (CPT-B). The distribution of the cryptic plasmids among the isolates from patients and the ward environment was interesting and surprising. No CPT-B-containing isolates were found among the 17 isolates from the dirty utility room (sluice) environment and only four plasmid-free isolates (PFI) were found; 13 $(76 \%)$ isolates were CPT-A. It is likely that the environment of the sluice and the urine jugs were contaminated by urine, and possibly faeces, from colonised patients. However, the distribution of cryptic plasmid types among strains isolated from the patients does not reflect that found in the environment. Of the eight patients known to be colonised, five were colonised only by PFI; a total of 27 isolates were obtained. The remaining three patients were colonised by strains containing plasmids: one patient had CPT-A and PFI strains, and the two other patients had CPT-A, CPT-B or PFI strains (all three types were isolated on one or more occasions). Thus the ratio of PFI to CPT-A strains in patients was 79 to 12 whereas in the environment it was 4 to 14 . It is possible that strains of $P$. stuarti containing CPT-A can survive better than PFI strains in the sluice-room environment. The failure to find CPT-B strains in the environment may be related to the finding that only two isolates were obtained from urine while the other 13 came from rectal, perineal or finger swabs. Alternatively CPT-B-containing $P$. stuarti may survive better in faeces or on skin than do CPT-A-containing strains.

It has been suggested that the plasmid content of a bacterial isolate may be a useful epidemiological marker (McGowan et al., 1979; Parisi and Hecht, 1980; Hughes et al., 1981; Sasarman et al., 1981; Riley and Cohen, 1982; Bezanson, Khakhria and Pagnutti, 1983). However, when an outbreak of hospital infection with Klebsiella aerogenes was investigated it was found that although all 56 examples of the epidemic strain, identical by capsular and klebecin typing, carried the same resistance plasmid, there was variation in the cryptic plasmid content of the isolates. Forty-nine isolates possessed a cryptic plasmid of mol. wt $70 \times 10^{6}$, four carried a cryptic plasmid of mol wt. $85 \times 10^{6}$ and three lacked a cryptic plasmid. These differences were ascribed to variation in a clone of bacteria in a hospital environment (Hughes et al., 1981). In the study reported here, two patients carried all three types of isolate (CPT-A, CPT-B and PFI) at various sites and at various times. Thus, a serologically homogeneous population of $P$. stuarti may contain a varying balance of both cryptic plasmid types 
and of plasmid-free bacteria. These findings suggest that there may be variation in populations of cryptic plasmids in $P$. stuarti isolated from closely related sources. As was noted in the introduction, it might be expected that the plasmid content of strains of a bacterial species is influenced by the environment from which they are isolated. Thus, plasmid analysis of a large number of strains isolated over a relatively short period in this study has shown that different plasmid types may predominate in different environments in the ward and this lends support to the above idea. Since plasmids may be lost or transferred from strain to strain, plasmid typing is perhaps most useful for subtyping populations of bacteria that are apparently homogeneous by other markers.

Although they are inconvenient to investigate, further studies of cryptic plasmids in gram-negative bacteria should be made, particularly because such plasmids may act as recipients for the transposition of antibiotic-resistance genes. Such a route of evolution has been suggested for the $\beta$-lactamase plasmids of Neisseria gonorrhoeae and Haemophilus influenzae (Roberts, Elwell and Falkow, 1977; Laufs et al., 1981).

This work was supported by a grant to PMH by the Bristol and Weston Health Authority Medical Research Committee. We thank Dr J. L. Penner for providing facilities for serotyping isolates.

\section{REFERENCES}

Bezanson G S, Khakhria R, Pagnutti D 1983. Plasmid profiles of value in differentiating Salmonella muenster isolates. Journal of Clinical Microbiology 17:1159-1160.

Farrar W E 1983 Molecular analysis of plasmids in epidemiologic investigation. Journal of Infectious Diseases 148:1-6.

Hansen J B, Olsen R H 1978 Isolation of large bacterial plasmids and characterization of the p2 incompatibility group plasmids pMGl and pMG5. Journal of Bacteriology 135:227-238.

Hawkey P M, Penner J L, Potten M R, Stephens M, Barton L J, Speller D C E 1982 Prospective survey of fecal, urinary tract, and environmental colonization by Providencia stuartii in two geriatric wards. Journal of Clinical Microbiology 16:422-426.

Hughes V M, Henderson W G, Datta N 1981 Discrimination between multiply-resistant Klebsiella strains during a hospital outbreak: use of Klebecin-typing and a screening test for plasmids. Journal of Hospital Infection 2:45-54.

Laufs R, Riess F-C, Jahn G, Fock R, Kaulfers P-M 1981 Origin of Haemophilus influenzae R factors. Journal of Bacteriology 147:563-568.

McCormick M, Wishart W, Ohtsubo H, Heffron F, Ohtsubo E 1981 Plasmid cointegrates and their resolution mediated by transposon Tn3 mutants. Gene 15:103-118.

McGowan J E, Terry P M, Huang T-S R, Houk C L, Davies J 1979 Nosocomial infections with gentamicin-resistant Staphylococcus aureus: Plasmid analysis as an epidemiologic tool. Journal of Infectious Diseases 140:864-872.

McHale P J, Keane C T, Dougan G 1981 Antibiotic resistance in Providencia stuartii isolated in hospitals. Journal of Clinical Microbiology 13:1099-1104.

O'Brien T F, Ross D G, Guzman M A, Medeiros A A, Hedges R W, Botstein D 1980 Dissemination of an antibiotic resistance plasmid in hospital patient flora. Antimicrobial Agents and Chemotherapy 17:537-543.

Parisi J T, Hecht D W 1980 Plasmid profiles in epidemiologic studies of infections by Staphylococus epidermidis. Journal of Infectious Diseases 141:637-643.

Penner J L, Hinton N A, Hennessy J N, Whiteley G R 1976 Reconstitution of the somatic (O-) antigenic scheme for Providencia and preparation of O-typing antisera. Journal of Infectious Diseases 133:283-292.

Riley L W, Cohen M L 1982 Plasmid profiles and Salmonella epidemiology. Lancet 1:573. 
Roberts M, Elwell L P, Falkow S 1977 Molecular characterization of two Beta-lactamase-specifying plasmids isolated from Neisseria gonorrhoeae. Journal of Bacteriology 131:557-563.

Robinson M K, Bennett P M, Richmond M H 1977 Inhibition of TnA translocation by TnA. Journal of Bacteriology 129:407-414.

Rubens C E, Farrar W E, McGee Z A, Schaffner W 1981 Evolution of a plasmid mediating resistance to multiple antimicrobial agents during a prolonged epidemic of nosocomial infections. Journal of Infectious Diseases 143:170-181.

Sasarman A, Massie B, Cousineau L, Tardif D, Proschek R, Martineau B 1981 Suspected epidemiological relationships among strains of Escherichia coli O55:B5 confirmed by restriction pattern analysis of the carried plasmid (RCo1 BM IncFIII). Annales Microbiologie (Institut Pasteur) 132B:387-398.

Schlaes D M, Currie C A 1983 Endemic gentamicin resistance R factors on a spinal cord injury unit. Journal of Clinical Microbiology 18:236-241.

Steers E, Foltz E L, Graves B S 1959 An inocula replicating apparatus for routine testing of bacterial susceptibility to antibiotics. Antibiotics and Chemotherapy 9:307-311.

Szybalski W, Bryson V 1952 Genetic studies on microbial cross resistance to toxic agents. 1. Cross resistance of Escherichia coli to fifteen antibiotics. Journal of Bacteriology 64:489-499.

Thompson R, Hughes S G, Broda P 1974 Plasmid identification using specific endonucleases. Molecular and General Genetics 133: 141-149.

Tietze E, Tschäpe H 1983 Plasmid pattern analysis of natural bacterial isolates and its epidemiological implication. Journal of Hygiene 90:475-488.

Tompkins L S, Plorde J J, Falkow S 1980 Molecular analysis of R-factors from multiresistant nosocomial isolates. Journal of Infectious Diseases 141:625-636. 